\title{
THE IMPACT OF THE CASE-LAW OF THE COURT OF JUSTICE OF THE EUROPEAN UNION IN THE FIELD OF PUBLIC PROCUREMENT
}

\author{
Albena IVANOVA \\ "Neofit Rilski”" South-West University, Blagoevgrad, Bulgaria \\ lexa777@abv.bg
}

\begin{abstract}
The article examines the case-law of the Court of Justice of the European Union on Public Procurement issues. On the one hand, the paper analyzes the control exercised by the Court in this area while the Member States implement the Public Procurement Directives by transposing them into national law or by administrative practice which is subject to judicial review. The Court's control is executed through the interpretation of provisions and through actions taken by the European Commission against Member States for breaches of EU law in the area of Public Procurement. On the other hand, in the references for a preliminary ruling, the Court of Justice of the EU defines some basic terms, such as 'public procurement' (at Union level), a contractor, a minimum threshold, etc., and affirms the key principles that must be respected for the fulfilment of Public Procurement objectives such as transparency, competition and equal treatment. The article aims to show the contribution of the case-law of the Court of Justice of the European Union to the development and uniform application of Public Procurement legislation in the Member States and facilitates the functioning of the Internal market.
\end{abstract}

\section{Keywords: public procurement, Court of Justice of the European Union, case-law}

\section{Introduction}

Public Procurement Law is ruled by the legal framework, which is basically formulated in Observance Law the control on which is performed by the judicial system of each Member State. European Union-wide control is carried out by the Court of Justice of the European Union (CJEU) when implementing a regulation or transposing directives into the national law of the Member States, including in the field of Public Procurement.

The Luxemburg Court's activity on the practical application of European Union law is of utmost importance. Firstly, it monitors the correct application of EU law in cases where the provisions of EU law have been violated, the Court interprets when necessary their proper and uniform application by all Member States. In the abovementioned field, the Court controls the fulfilment and enforcement of Public
Procurement Directives by the EU countries through their transposition into national law. This control is carried out through the interpretation of the relevant provisions and through procedures for actions taken by the European Commission against Member States for breaches of European Union Law in the Public Procurement scope. On the other hand, in the references for a preliminary ruling, the Court of Justice of the European Union draws up basic concepts in that subject, such as what is a public contract (at Union level), a contracting authority, a minimum threshold, etc., and defines the content of the key principles which must be respected for the achievement of Public Procurement aims, such as transparency, competition and equal treatment. 


\section{Forms of judicial control}

The adoption of new Directives in the area of Public Procurement has been required by the changed European Union remit in recent years stemming from the different challenges faced by the Union in the last decade, which is linked to an increase in the large number of immigrants and the need for Member States correctly and quickly to meet the urgent needs of these people (accommodation, supplies and services). [1] The response from the Commission and other EU institutions were a new EU Public Procurement Directives which were adopted on 26 February 2014. They are as follows: Directive 2014/23/EU on the award of concession contracts; Directive 2014/24/EU on Public Procurement; Directive 2014/25 on the procurement of contracting entities operating in the water, energy, transport and postal services sectors. The new directives entered into force on 17 April 2014 and set a deadline of 18 April 2016 to be transposed by all Member States of the European Union into their national legislation.

Article 1, par.2 of Directive 2014/24/EU of the European Parliament and of the Council, gives the definition of a public contract: "Procurement in the sense of this Directive is the acquisition through a public contract of works, supplies or services by one or more contracting authorities from economic operators selected by those contracting authorities, whether or not the works, supplies or services are intended for public purpose". This legal definition is also adopted in the Bulgarian legislation, in Article 1 of the Bulgarian Public Procurement Law (SG, No. 13 of 16.02.2016), which introduces the Directive in our country. As the Bulgarian authors have noted in their comments to the new law, there is a new approach towards 'public procurement' accepted in the definition of Article 1, par. 2 (a) compared to the definition in older Directive 2004/18/EC which describes it only as a contract. The new point is that the term "assignment" includes both the procedure and the conclusion of the contract. The authors have also mentioned that the structure of the system of Public Procurement has changed and many new moments have been introduced in Directive 2014/24/EU, such as the innovation partnership, the liberalization of the arrangements for participation in procedures, a new way of formulating the award criteria, the annulment of the requirement for guarantees of participation in procedures, etc. [2]

The CJEU case-law in the field of Public Procurement is constant, albeit not very new, in view of the fact that the package of new Directives has been applied relatively recently. In its jurisprudence, the Luxembourg Court monitors the implementation of the Public Procurement Directives by the Member States at a national level and controls the compliance with administrative practice at European Union level when this stems from the specificities of the case. The judicial control over the Public Procurement legal regime can be seen as horizontal and vertical. Its horizontal effect is manifested at European Union level when implementing the socalled centralized control, which is mainly applied by the European Commission through proceedings under Article 258 Treaty on Functioning of the European Union (TFEU). The vertical effect is manifested in decentralized judicial control through disputes arising from the application of Public Procurement Law at a national level and in a large number preliminary ruling questions brought by national courts to the CJEU under Article 267 TFEU on the interpretation of the provisions of the Public Procurement Directives. The models that present how centralized and decentralized judicial control show the impact of public procurement legislation on demand and supply of public procurement outlined in the doctrine are two. [3]. The first type of cases are those of Union law. They have been instituted against defaulting Member States that have failed to implement the Public Procurement Directives in their national legal systems on time and/or correctly. The second type of cases are related to the 
creation of a permanent, unified practice in the area of Public Procurement by clarifying and interpreting the provisions of the EU secondary legislation by the Luxembourg Court within the framework of the procedure under Article 267 TFEU.

The primary EU law (TFEU) regulates mainly the centralized judicial review, including the proceedings under Articles 258, 259 and 260 thereof. This is because the forms and methods of incorporating the provisions of the Directives into national law are mainly given to Member States' choice and freedom of action. In Bulgarian public law, most of the Directives are introduced through laws, as in the case of the Council Directive 2006/112 /EC of 28 November 2006 on the common system of value added tax the Value Added Tax Directive and the Directive 2014/24/EU on Public Procurement [4].

Centralized judicial control, as mentioned above, ensures that EU countries will fulfill their obligations. The control exercised by the Court on the application of European Union law is often closely linked to the control functions of the European Commission.

The establishment of infringements by the European Commission may be on its own initiative or on a complaint by one Member State against another for failure to comply with its obligations under the Treaty due to lack of action that may also occur in the field of public procurement. In these proceedings, the European Commission does not need to establish a legal interest in that; it is out of the eligibility conditions of the complaint - it is the Commission's common duty to observe, control and guarantee the correct application of the EU Law. Moreover, in cases where national litigation was withdrawn, the Commission has initiated proceedings against Spain for not complying with the provisions of the Public Procurement Directive, based on incongruity with the principles and provisions of the law on Public Procurement framework of the agreement concluded between the Spanish public authorities and the National
Association of Pharmaceutical Companies (C-179/89 - Farmaindustria.)

In its permanent vision, mainly by clarifying and interpreting the provisions of the Public Procurement Directives, the CJEU interprets and promotes the basic concepts in this matter, so there is no doubt about their content in their application. Some features are common to all types of contracts covered by the Directive, which can be inferred from the case law. In its case-law, the CJEU has also defined and commented on two other main concepts. The first one is the idea of a peculiar interest - in the Public Procurement the contract is a 'contract of repayment' and the repayment is linked not only to the payment of remuneration for the public contract works and the consideration offered to the service provider in return for the provision of the services specified by the contracting authority concerned. "The nonprolific nature of a contract concerns the consideration given to the contractor in relation to the performance of the works specified by the contracting authority".[5] The second concept concerns the economic contractor and contracting body. For example, according to established EU caselaw, in order to qualify as a contractor, person or entity requiring a public procurement contract, the contracting authority may conclude such a contract only with that person (contractor) who is directly capable of performing the agreed service by own funds.[6] As to the meaning of 'contracting authorities', the Court accepts a broad functional definition in order to respect the objective of the Public Procurement Directive and, therefore, gives full effect to the common market fundamental freedoms. [7]

\section{Case law on general principles in the area of Public Procurement}

The principles represent the fundament of Public Procurement, as they are at the core of the Internal Market. The Bulgarian legal doctrine maintains that there are two elements in the concept of the Internal Market. The first is the territory outlined by 
the borders of the Member States, where all restrictions on the realization of the four fundamental freedoms of movement must be removed. The second element refers to the freedoms and the principles that characterize them, which are the general principles of EU law. [8] [9] One of the main aims of Public Procurement is to be a guarantor for the free movement of people, goods, services, and capital, which is achieved precisely through transparent procedures in which the participants are equal and nondiscriminated.

The provision of Article 18, par. 1 of Directive 2014/24/EU defines its basic principles as follows: "The contracting authorities shall treat the economic operator in a transparent and proportionate manner". In paragraph 2 of the same provision another requirement is introduced - conducting of the auctions should be in compliance with the competition principle without introducing special criteria aimed at narrowing the circle of participants. Many times in its practice, the Court of Justice has defined and clarified the importance of these principles. In the motives of the Decision in case C-368/10, Commission v Netherlands, the CJEU reminds that the established the case-law accepts that the principle of transparency is respected when all the requirements of the award procedure are indicated in a clear, precise and unambiguous way in the contract notice or the procurement documentation, so as "to enable all informed and serious candidates to understand their exact scope and to interpret them in a uniform manner and to allow the contracting authority to effectively verify that the tenders meet the criteria laid down".[10]. This also applies to the observance of the principles of equality, non-discrimination and transparency, which require the award criteria to be objective in order to ensure objective comparison and evaluation of tenders in order to create and operate an objective competition. [11]
In its decision in case C-568/13 - Data Medical Service, the Luxembourg Court also points out that "one of the objectives of the Union's rules on Public Procurement is to open up to the widest possible competition, an opening which is also in the interest of the contracting authority concerned, which would thus have a greater choice" [12]

The jurisprudence of the CJEU has found that even in low-value contracts, crossborder interest may be observed, in certain circumstances, when national borders cross urban agglomerations. [13] For service concessions and non-priority services for which no publication of a contract notice is required in the Official Journal of the European Union, the same principle of cross-border interest applies according to EU legislation [14]. The court found in its practice that Article 37 of Directive 92/50 does not define the concept of 'abnormally low value' and, in that regard, the concept of 'the contracting authorities of the Member States must determine the method of calculating an unusual threshold which constitutes an' abnormally low tender 'within the meaning of that provision" [15].

In several decisions, the Luxembourg Court sets out the conditions to be met in order to classify land-related contracts as public works contracts. [16]

\section{Conclusion}

From this brief analysis of the CJEU jurisprudence, a well-founded conclusion can be drawn that the existence of Public Procurement, such as the legal system and the procedural framework, is essential for the proper application of EU law in this area. The contribution of the Court of Justice of the European Union to the development and implementation of Public Procurement Law is of exceptional value and contributes to the uniform application of Public Procurement legislation across the Member States and to the further development of the Internal Market. 


\section{References}

[1] Communication from the Commission to the European Parliament end the Council on Public Procurement rules in connection with the current asylum crisis, Brussels, 9.9.2015, COM(2015) 454 final, Page 2, http://www.europarl.europa.eu;

[2] Markov M., E. Dimova, A. Aleksandrov, M. Katsarova, The new legal framework for public procurement and the management of European funds, 2016, in Bulgarian, Sofia, Trud i Pravo, pp. 18-19, 22-23;

[3] Bovis Chr., EC Public Procurement: Case Law and Regulation, Oxford, Oxford University Press, 2006, pp. 49-50;

[4] Minkova G., N.Chilova., Tax Law Handbook, in Bulgarian, Sofia, Ciela, 2015, p. 15;

[5] C-220/05 - Auroux and Others, ECLI: EU:C 2007: 31, par.38 and 44 and C-382/05 Commission v Italy, ECLI: EU: C :2007: 445, par.39;

[6] C-368/10, Commission v Netherlands, ECLI :EU: C:2012 :284, par.39,62 and 88 and C84/03 - Commission v Spain ECLI:EU:C:2005:14, par.38;

[7] C-368/10, Commission v Netherlands, ECLI:EU:C:2012:284, par.39,62 and 88 and C84/03 - Commission v Spain ECLI:EU:C:2005:14, par.38

[8] Marin N, P. Dimitrov, Economic Effects of the membership of the Republic of Bulgaria in the European Union, Kutafin University Law Review 1/2018, in print;

[9] Belova G., N. Marin, G. Georgieva, Y.Kochev, New Moments in Personal Data Protection in the European Union, Scientific papers of Institute of legal studies Bulgarian Academy of Sciences (Journal), Vol. XVI, pp. 54-64, 2017;

[10] C-368/10, Commission v Netherlands, ECLI:EU:C:2012:284,

[11] C-306/97 - Connemara Machine Turf, ECLI:EU:C:1998:623, par.30-31 and C-353/96 Commission v Ireland, ECLI:EU:C:1998:611, par.35-36;

[12] C-568/13 - Data Medical Service, ECLI:EU:C:2014:2466 and C -337/06 Bayerischer Rundfunk and Others, ECLI:EU:C:2007:786, par.39;

[13] C-147/06, SECAP SpA and, C-148/06 Santorso v. Comune di Torino, ECLI: EU: C: 2008:277;

[14] C-226/09, Commission v Ireland, ECLI:EU:C:2010:697;

[15] C-285/99 and C-286/99, Lombardini and Mantovani, ECLI:EU:C:2001:640, par.67;

[16] C-220/05 Auroux and Others, ECLI: EU: C: 200 :31 and C-451/08 Helmut Müller, ECLI: EU :C: 2010:168; 